Papers and Proceedings of the Royal Society of Tasmania, Volume 116, 1982

(ms. received 17.12 .81 )

\title{
A NOTE ON THE REPORTED OCCURRENCE OF STEEPLY-DIPPING TERTIARY BEDS ON OSMIRIDIUM BEACH, SOUTHERN TASMANIA
}

by R.F. Berry and S. Harley

Department of Geology, University of Tasmania

(with one text-figure)

ABSTRACT

BERRY, R.F. and HARLEY, S., 1982 (31 viii): A note on the reported occurrence of steeplydipping Tertiary beds on Osmiridium Beach, southern Tasmania. Pap. Proc. R. Soc.

Tasm., 116: 179-180. https://doi.org/10.26749/rstpp.116.179

ISSN 0080-4703. Department of Geology, University of Tasmania.

The steeply dipping beds at Osmiridium Beach, southern Tasmania, earlier identified as Tertiary are structurally and stratigraphically continuous with the ?Cambrian Pt Vivian Formation. The carbonaceous layers, used to support a Tertiary age, cut across the bedding and postdate some faults in the formation.

Twelvetrees (1915) reported a sequence of variably-dipping Tertiary strata from the western end of Osmiridium Beach. The steeply-dipping beds in this sequence were identified as Tertiary because of the carbonaceous zones which continue into them from overlying poorly-consolidated material including seams of brown coal. A sample of the carbonaceous material contained several angiosperm pollens which indicate a Late Cretaceous to Recent age (D. Taylor, pers. comm.) .

The vertically-dipping beds of conglomerate and siltstone are lithologically indistinguishable from, and structurally continuous with those of the ?Cambrian Pt Vivian Formation (Berry and Harley, in prep.). Since the Pt Vivian Formation was folded during the Devonian orogeny a disconformity is unlikely at its boundary with the steeply-dipping beds claimed by Twelvetrees to be Tertiary. Also, the structural fabric of the siltstones does not change across this boundary. In addition, a set of shallowly-dipping quartz veins are continuous across the boundary proposed by Twelvetrees and a few quartz pebbles are offset along these surfaces indicating that the matrix, now poorly cemented due to weathering, was originally capable of transmitting substantial stresses to the pebbles.

Carbonaceous zones within the steeply-dipping beds were considered by Twelvetrees to continue into the overlying sediments. However the intensity of weathering of the steeply-dipping layers increases within $5 \mathrm{~m}$ of the angular unconformity with overlying poorly consolidated gravel. The vertical carbonaceous layers generally start at this boundary (fig. 1), crosscut the layering, and in one case form a distinct zone in a fault within the conglomerates. Some of the carbonaceous layers contain recognizable roots which are continuous along the zone for more than a metre. We interpret these carbonaceous zones as cracks filled with organic matter and clay during weathering and erosion before the overlying quartz pebble conglomerate was deposited.

At the eastern end of the outcrop there is a very weathered brown rock with randomly oriented root-like pieces of carbonaceous material. This is probably a fossil soil which survived as a pocket projecting downward into the ?Cambrian rocks from the angularly unconformable base of the poorly consolidated younger gravel. 
Steeply-dipping Tertiary beds, southern Tasmania

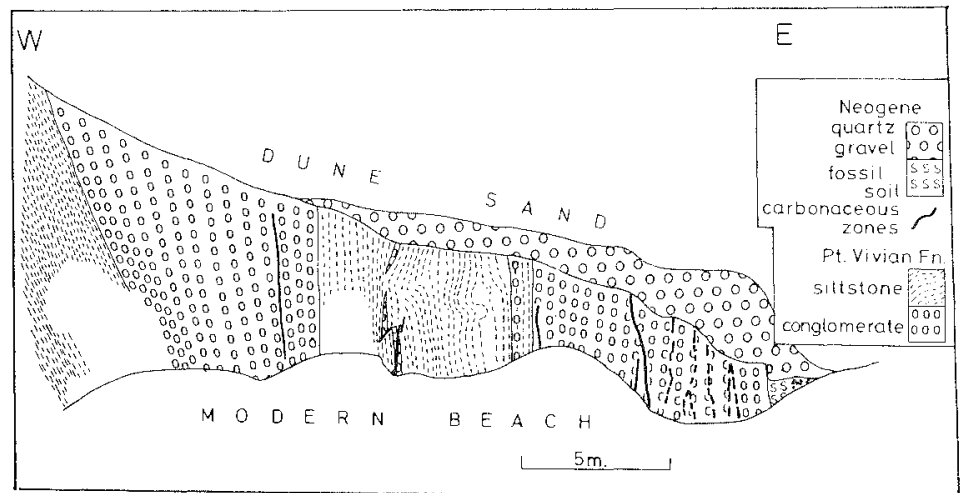

FIG. 1.- Sketch section of the rocks outcropping at the western end of Osmiridium Beach.

REFERENCES

Berry, R.F. and Harley, S., in prep.: Stratigraphy and structure of the Prion BeachRocky Boat Inlet-Osmiridium Beach coastal section, southern Tasmania.

Twelvetrees, W.H., 1915: Reconnaissance of the country between Recherche Bay and New River, southern Tasmania. Bull. geol. Surv. Tasm. 24. 